\title{
PENGARUH PEMBERDAYAAN DAN PEMBELAJARAN ORGANISASI TERHADAP KOMITMEN ORGANISASI DOSEN SEKOLAH TINGGI ILMU TARBIAH AL-AMIN, TANGERANG SELATAN.
}

\author{
Lilis Sakuroh. ${ }^{1}$
}

\begin{abstract}
The purpose of this research is to determine the effect of empowerment and organizational learning on organizational commitment the Lecture STTI Al-Amin. The research methodology was survey which were selected by simple random sampling technique. Analysis and interpretation of the data indicate that (1) organizational structure has a positive direct effect in productivity, (2) job design has a positive direct effect in productivity, (3) organizational structure has a positive direct effect in job design.
\end{abstract}

Keywords: organizational structure, job design, productivity.

\section{PENDAHULUAN}

Peningkatan akses pendidikan tinggi bagi gnerasi muda tetap menjadi perhatian utama kementrian Riset, Teknologi, dan Pendidikan. Namun penyedian akses tersebut tidak serta merta memberikan izin pendirian perguruan tinggi baru. Sebab jaminan mutu layanan mutu pendidikan tinggi juga harus menjadi prioritas. Adanya kebijakan otonomi pendidikan, memberikan peluang dan sekaligus tantangan bagi setiap daerah, lembaga pendidikan serta perguruan tinggi swasta (PTS) untuk mengembangkan dan mewamai pendidikan sesuai dengan karakteristik dan kebutuhan masyarakat di daerah masing-masing. Sekolah Tinggi Ilmu Tarbiyah "Al-Amin" (SK Dirjen Pendis : No. DJ.1/177/2007 \& Terakreditasi SK BAN-PT NO. 001/BAN-PT/Ak-XIV/Si/ V/2011) memberikan tawaran alternatif untuk memenuhi kebutuhan ini dan mewujudkan sumber daya Manusia (SDM) berkualitas yang mampu merespon tantangan globalisasi dan siap menghadapi situasi yang sangat kompetitf tersebut.

Ainun Naim mengatakan, angka partisipasi kasar (APK) perguruan tinggi terus ditingkatkan. Pada tahun 2019 pemerintah menargetkan 36 persen generasi muda menikmati pendidikan tinggi. Berdasarkan data pencapaian indikator program tahun 2015, APK ditargetkan 26.86 persen dan naik menjadi 28.16 persen tahun 2016. Peningkatan angka partisipasi kasar pendidikan memang tidak seagresif sebelumnya. Pemerintah ingin peningkatan kualitas pendidikan tinggi sejalan dengan perluasan akses. Dapat dikatakan bahwa pendidikan formal merupakan satu cara untuk meningkatkan kemampuan individu dosen dan bahwa organisasi memperoleh keuntungan dari berbagai aktivitas individu terdidik (Dosen) tersebut. Berdasarkan pandangan ini, pembelajaran merupakan sebuah fenomena dimana organisasi memperoleh keuntungan dari dosen yang terampil. Sekarang ini, pembelajaran individu tidak menjamin pembelajaran organisasi, tetapi pembelajaran organisasi tidak akan terjadi tanpa pembelajaran individu.

Peningkatan mutu pendidikan di Indonesia di iringi dengan beberapa kebijakan yang di keluarkan seperti peningkatan jumlah doktor untuk menjadi dosen dan peneliti

1 Dosen Sekolah Tinggi IImu Tarbiah Al-Amin,Tangerang Selatan. 
didorong lewat program magister menuju doktor untuk sarjana unggul. Sarjana terbaik di Indonesia dapat mengakses beasiswa doktor yang di biayai mulai dari jenjang magister di 12 perguruan tinggi negeri ternama di Indonesia. Selanjutnya Ali Gufron mengatakan jumlah doktor di perguruan tinggi masih kurang, saat ini tercatat jumlah dosen berpendidikan S-2 sebanyak 126.749 dosen. Adapun dosen berpendidikan S-3 sebanyak 23.827 dosen, sedangkan guru besar sekitar 5.000 dosen. Dengan bertambahnya doktor diharapkan bisa mendongrak publikasi ilmiah dan inovasi yang nantinya bisa di manfaatkan masyarakat. Karena itu penting bagi pemerintah untuk menyediakan banyak doktor, utamanya untuk kebutuhan sebagai dosen dan peneliti di kampus. Ansori mengatakan penerima beasiswa PMDSU bergantung pada ketersediaan anggaran negara, diharapakan tiap thun bertambah, pada awal di luncurkan beberapa tahun lalau, di gelombang pertama pendaftar hanya 71 dosen dan yang diterima 57 dosen dengan 27 promotor. Di gelombang berikutnya, peminat meningkat 3.459 orang yang diterima 134 orang. Pada tahun ini, peminat berjumlah 1.736 orang yang diterima 202 orang. Beasiswa ini diperuntukan bagi sarjana unggul, yang memiliki IPK minimal 3.25. adapun promotor memiliki keahlian di bidangnya dan memiliki H-indeks menimal 2 pada data scopus.com.

Sekolah Tinggi Ilmu Tarbiah (STIT) Al-Amin dalam menyelenggarakan perkuliahan untuk program S1 selain perkuliahan reguler, juga dilaksanakan perkuliahan Non Reguler (intensif), untuk memberikan kesempatan kepada PNS, karyawan dan para eksekutif yang sibuk bekerja dengan waktu kuliah sabtu atau minggu, dengan tenaga pengajar yang professional dan kompeten dibidangnya. Dalam melaksanakan tugas dan fungsi pengajar seperti yang disebutkan di atas, dosen menghadapi berbagai kendala dan masalah diantaranya mengenai rendahnya komitmen dosen. Kurangnya komitmen dosen sehingga tujuan organisasi tidak tercapai secara optimal. Peningkatan komitmen organisasi dosen dengan pola penggunaan yang ada saat ini, dirasakan belum dapat memenuhi kriteria "The Right Man on The Right Place", sehingga perlu adanya peningkatan komitmen organisasi, dan pembuatan sistem ataupun metode baru yang lebih baik dalam bentuk pola pembinaan profesi dan pola penilaian dosen. Sebagaimana yang telah dijelaskan sebelumnya, komitmen organisasi atau rasa keterikatan dosen terhadap lembaga pendidikan tempat mereka bekerja dapat dipengaruhi oleh partisipasi dalam pemberdayaan dan pembelajaran organisasi (tempat dimana dosen tersebut menyalurkan kompetensinya). Meskipun tidak secara keseluruhan terjadi pada setiap dosen namun secara umum dapat dikategorikan hampir seluruhnya.

Konsep pembelajaran individu menjelaskan secara implisit bahwa manusia memiliki kemampuan untuk belajar dan berubah untuk mencapai pendewasaan dirinya. Manusia diharapkan untuk selalu mau belajar mengenai lingkungannya (outside in down), dan sekaligus mengenal dan kemudian mengaktualisasikan dirinya (inside up out). Diharapkan manusia mampu menempatkan dirinya sesuai dengan kapasitas dirinya, sehingga ia dapat memberikan kontribusi terbaik minimal untuk dirinya, dan lebih luas untuk menciptakan kesejahteraan bagi organisasi, masyarakat atau lingkungannya. 
Perbedaan terjadi pada jumlah anggota yang terlibat, sehingga konsep utama dari proses pembelajaran organisasi adalah belajar bersama melibatkan seluruh anggota organisasi, dimana mekanisme berbagi baik berbagi cara berpikir, berbagi cara pandang, berbagi model mental atau berbagi visi bersama menjadi kunci utama keberhasilan dari proses pembelajaran organisasi, dan setelah pembentukan pengetahuan organisasi, dilanjutkan dengan proses institusionalisasi untuk mengubah pengetahuan tacit (pengetahuan yang masih tersimpan didalam pemikiran manusia) organisasi menjadi pengetahuan explicit organisasi.Di dalam upaya mewujudkan visi STIT Al-Amin, yaitu "mewujudkan lembaga pendidikan tinggi yang terkemuka dalam mengembangkan dan mengintegrasikan aspek kesilaman, keilmuan dan pengalaman dan kemanusian" pihak yayasan melakukan beberapa terobosan di antaranya dengan melakukan pemberdayaan kepada dosen-dosen dalam upaya peningkatan kualitas, komitmen terhadap yayasan dan pembelajaran organisasi, melalui melakukan kerjasama kepada beberapa PTN dengan membuat MoU pelatihan dan riset bersama.

Berdasarkan penjelasan di atas, penting untuk dilakukan dalam upaya untuk mengetahui pengaruh pemberdayaan dan pembelajaran organisasi terhadap komitmen organisasi dosen.

\section{Komitmen Organisasi}

Komitmen terhadap organisasi artinya lebih dari sekedar keanggotaan formal, karena meliputi sikap menyukai organisasi dan kesediaan untuk mengusahakan tingkat upaya yang tinggi bagi kepentingan organisasi demi pencapaian tujuan. Pendapat Timothy T. Baldwin, William H. Bommer, dan Robert S. Rubin (2013:243) mendefinisikan komitmen organisasi sebagai berikut, "organizational commitment is an attitude representing the extent to which an employee identifies with his organization and desires to remain a member of the organization". Komitmen organisasi adalah suatu sikap yang mencerminkan sejauh mana seorang karyawan mengidentifikasi dengan organisasi dan keinginan untuk tetap menjadi anggota organisasi.

John R. Schemerhorn, JR, Richard N. Osborn, Mary Uhl-Bien, dan James G. Hunt (2012:63) mendefinisikan komitmen organisasi sebagai berikut, "organizational commitment is the loyalty of an individual to the organization". Komitmen organisasi adalah loyalitas seorang individu untuk organisasi. Komitmen dosen akan terlihat dari loyalitas dirinya terhadap kampus, dengan membantu untuk memajukan kampus lebih baik lagi. Selanjutnya Jason A. Colquitt, Jeffry A. LePine, dan Michael J Wesson (2015:64) mendefinisikan komitmen organisasi sebagai berikut, "organizational commitment is defined as the desire on the part of an employee to remain a member of the organization, organizational commitment influences whether an employee stays a member of the organizational (is retained) or leaves to pursue another job". Komitmen organisasi didefinisikan sebagai keinginan dosen untuk tetap menjadi anggota organisasi, komitmen organisasi mempengaruhi apakah seorang dosen akan tetap menjadi anggota organisasi atau mengejar pekerjaan lain yang mempunyai pendapatan yang lebih besar dari penghasilan sebagai dosen dikampus tersebut.

Selanjutnya Stephen P. Robbins, dan Timothy A. Judge (2015:102) mendefinisikan komitmen organisasi sebagai berikut, "organizational commitment is the degree to which an employee identifies with a particular organization and its goals and wishes to maintain membership in the organization". Komitmen organisasi adalah sejauh mana 
seorang karyawan mengidentifikasi dengan organisasi tertentu dan tujuan dan keinginan untuk mempertahankan keanggotaan dalam organisasi.

Berdasarkan uraian di atas, dapat disintesiskan bahwa yang dimaksud dengan komitmen organisasi adalah keberpihakan seseorang sebagai anggota tetap organisasi terhadap organisasinya dengan berperan aktif serta bertangung jawab dalam rangka untuk mencapai tujuannya, dengan indikator, bersikap setia atau loyal kepada organisasi, sikap mengidentifikasi terhadap organisasi, memiliki usaha dan harapan yang kuat untuk tetap berada dalam organisasi.

\section{Pemberdayaan}

Memberdayakan dapat dinyatakan sebagai suatu hal yang mendorong untuk menjadi lebih terlibat dalam mengambil keputusan dan beraktivitas yang berhubungan dengan pekerjaan. Setiap individu dalam pemberdayaan memungkinkan membuat keputusan lebih besar dan lebih banyak tanpa harus mengacu pada sesorang yang lebih senior. Edwin P. Hollander dan Lynn R. Offermann, yang di kutip oleh Ricard L. Daft (2010:271) mendefinisikan pemberdayaan sebagai berikut, "empowerment is power sharing, the delegation of power or authority to subordinates in an organization". Pemberdayaan adalah pembagian kekuasaan, pendelegasian kekuasaan atau wewenang kepada bawahan dalam suatu organisasi.

Pendapat lain oleh Robert C. Ford dan Myron D. Fottler yang di kutip oleh John W. Neswtrom (2014:195) mendefinisikan pemberdayaan sebagai berikut, "empowerment is any process that provides greater autonomy to employees through the sharing of relevant information and the provision of control over factors affecting job performance". Pemberdayaan adalah proses yang menyediakan otonomi yang lebih besar kepada karyawan melalui berbagi informasi yang relevan dan penyediaan kontrol atas faktor yang mempengaruhi prestasi kerja. Hal senada di ungkapkan oleh Robert Kreitner, dan Angelo Kinicki (2011:442) mendefinisikan pemberdayaan sebagai berikut, "empowerment is recognizing and releasing into the organization of power that people already have their wealth of useful knowledge, experience and internal motivation." Pemberdayaan adalah perilaku dengan sadar dan melepaskan ke dalam kekuasaan organisasi. Dengan kekayaan pengetahuan yang dimiliki dan bermanfaat bagi organisasi, pengalaman dan motivasi internal seseorang. Hal senada di ungkapkan oleh Jenniver M George dan Gareth $\mathrm{R}$ Jones (2013:322) mendefinisikan pemberdayaan sebagai berikut; "empowerment the process of giving employees at all levels the authority to make decisions, be responsible for their outcomes, improve quality and cost is becoming increasingly popular in organization". Pemberdayaan adalah proses pemberian karyawan di semua tingkatan kewenangan untuk membuat keputusan, bertanggung jawab untuk hasil mereka, meningkatkan kualitas dan biaya menjadi semakin populer dalam organisasi.

Berdasarkan beberapa konsep yang telah dikemukakan dapat disintesiskan bahwa pemberdayaan adalah pemberian kekuasaan yang dilakukan dalam memanfaatkan dan pengembangkan potensi pegawai untuk meningkatkan kinerja pegawai dalam mencapai tujuan organisasi dengan indikator pemberian otonomi dalam bekerja, pemanfaatan sumber daya, dan upaya peningkatkan partisipasi pegawai. 


\section{Pembelajaran Organisasi}

Pembelajaran organisasi merupakan perolehan atau pencapaian pengetahuan, baik secara individu maupun kelompok yang ditetapkan dalam upaya pencapaian tujuan organisasi. ini berarti bahwa pembelajaran yang dilakukan oleh anggota organisasi harus merupakan bagian dalam suatu kesisteman organisasi, aplikasi hasil belajar yang terjadi akan dapat menjadi pendorong dan pendukung utama dalam upaya perbaikan organisasi, karena oleh seluruh anggota organisasi, Finger dan Brand yang di kutip oleh Uhar Saharsaputra (2015:71) mengungkapkan, "organizational learning is the activity and the process by which organizations eventually reach the ideal of a learning organization". Pembelajaran organisasi adalah kegiatan dan proses dimana organisasi akhirnya mencapai cita-cita organisasi belajar.

Jennifer M. George, dan Gareth R. Jones (2012:148) mengatakan, “organization learning the process through which managers instill in all members of an organization a desire to find new ways to improve organizational effectiveness". Pembelajaran organisasi adalah proses melalui manajer untuk menanamkan kepada semua anggota organisasi untuk menemukan cara-cara baru untuk meningkatkan efektivitas organisasi.

Hal senada di ungkapkan oleh John R. Schemerhon, JR, Richard N. Osbon, Mary Uhl-bein dan James G. Hunt (2012:401) mengatakan; "organizational learning is the process of acquiring knowledge and using information to adapt successfully to changing circumstances. for organizations to learn, they must engage in knowledge acquisition, information distribution, information interpretation and organizational retention in adapting successfully to changing circumstances". Pembelajaran organisasi adalah proses memperoleh pengetahuan dan menggunakan informasi untuk beradaptasi dengan sukses untuk keadaan yang berubah. untuk organisasi untuk belajar, mereka harus terlibat dalam akuisisi pengetahuan, distribusi informasi, interpretasi informasi dan retensi organisasi dalam beradaptasi dengan sukses untuk mengubah keadaan.

Berdasarkan definisi konsep yang telah diuraikan dapat disintesiskan pembelajaran organisasi adalah proses yang dilakukan pimpinan terhadap semua anggota organisasi untuk menemukan cara-cara baru dalam meningkatkan efektivitas organisasi, dengan indikator, memperoleh pengetahuan baru, proses menfasilitasi pembelajaran dan proses pemanfaatan pengetahuan.

\section{METODE PENELITIAN}

Penelitian ini menggunakan metode survey dengan teknik analisis jalur (path analys) Data penelitian ini dikumpulkan dengan cara memilih sampel dalam populasi. Populasi terjangkau dalam penelitian ini adalah seluruh dosen tetap STIT Al-Amin yang berjumlah 107 dosen. Dan perhitungan dengan menggunakan slovin, maka di peroleh jumlah sampel sebanyak 84 dosen yang dijadikan sampel frame dalam penelitian ini. Pengumpulan data digunakan untuk penelitian ini adalah statistika deskriptif dan statistika inferensial. 


\section{HASIL PENELITIAN DAN PEMBAHASAN}

\section{Pengaruh pemberdayaan terhadap komitmen organisasi.}

Dari hasil pengujian hipotesis pertama dapat disimpulkan bahwa terdapat pengaruh langsung positif pemberdayaan terhadap komitmen organisasi dengan nilai koefisien korelasi sebesar 0,459 dan nilai koefisien jalur sebesar 0,348. Ini memberikan makna pemberdayaan berpengaruh langsung terhadap komitmen organisasi. Timothy T. Baldwin, William H. Bommer, dan Robert S. Rubin (2013:243) mendefinisikan komitmen organisasi sebagai berikut, "organizational commitment is an attitude representing the extent to which an employee identifies with his organization and desires to remain a member of the organization". Komitmen organisasi adalah suatu sikap yang mencerminkan sejauh mana seorang karyawan mengidentifikasi dengan organisasi dan keinginan untuk tetap menjadi anggota organisasi. John R. Schemerhorn, JR, Richard N. Osborn, Mary Uhl-Bien, dan James G. Hunt (2012:63) mendefinisikan komitmen organisasi sebagai berikut, "organizational commitment is the loyalty of an individual to the organization". Komitmen organisasi adalah loyalitas seorang individu untuk organisasi. Komitmen dosen akan terlihat dari loyalitas dirinya terhadap kampus, dengan membantu untuk memajukan kampus lebih baik lagi. Selanjutnya Jason A. Colquitt, Jeffry A. LePine, dan Michael J Wesson (2015:64) mendefinisikan komitmen organisasi sebagai berikut, "organizational commitment is defined as the desire on the part of an employee to remain a member of the organization, organizational commitment influences whether an employee stays a member of the organizational (is retained) or leaves to pursue another job". Komitmen organisasi didefinisikan sebagai keinginan dosen untuk tetap menjadi anggota organisasi, komitmen organisasi mempengaruhi apakah seorang dosen akan tetap menjadi anggota organisasi atau mengejar pekerjaan lain yang mempunyai pendapatan yang lebih besar dari penghasilan sebagai dosen dikampus tersebut. Sedangkan Stephen P. Robbins, dan Timothy A. Judge (2015:102) mendefinisikan komitmen organisasi sebagai berikut, "organizational commitment is the degree to which an employee identifies with a particular organization and its goals and wishes to maintain membership in the organization". Komitmen organisasi adalah sejauh mana seorang karyawan mengidentifikasi dengan organisasi tertentu dan tujuan dan keinginan untuk mempertahankan keanggotaan dalam organisasi.

Hasil penelitian ini senada dengan pendapat beberapa ahli di antaranya adalah Stephen P. Robbins, dan Timothy A. Judge (2015:423) mengatakan melalui pemberdayaan dalam meningkatkan peran serta anggota dan akan berdampak kepada peningkatan komitmen organisasi dimana di bekerja, "psychological empowerment employees belief in the degree to which they affect their work,environment, their competence, the meaningfulness of their job and their perceived authonomy in their works". Dosen dapat memperkirakan sejauh mana mereka dapat mempengaruhi lingkungan kerja, kompetensi, kebermaknaan dalam pekerjaan dan kebebasan yang mereka rasakan dalam bekerja di kampus. Selanjutnya John R. Schermerhorn, Jr.,Richard N. Osbor, Mary Uhl-Bien, James G. Hunt (2011:452), "psychological empowerment a sense of personal fulfillment and purpose that arousesone's feelings of competency and commitment to the work". Maksudnya pemberdayaan merupakan rasa yang didapat untuk memenuhi keinginan dan tujuan dosen untuk membangkitkan perasaan terhadap kompetensi dan komitmen untuk bekerja. 


\section{Pengaruh pembelajaran organisasi terhadap komitmen organisasi.}

Dari hasil pengujian hipotesis kedua dapat disimpukan bahwa terdapat pengaruh langsung positif pembelajaran organisasi terhadap komitmen organisasi dengan nilai koefisien korelasi sebesar 0,452 dan nilai koefisien jalur sebesar 0,337. Ini memberikan makna pembelajaran organisasi berpengaruh langsung terhadap komitmen organisasi. Finger dan Brand yang di kutip oleh Uhar Saharsaputra (2015:71) mengungkapkan, "organizational learning is the activity and the process by which organizations eventually reach the ideal of a learning organization". Pembelajaran organisasi adalah kegiatan dan proses dimana organisasi akhirnya mencapai cita-cita organisasi belajar. Jennifer M. George, dan Gareth R. Jones (2012:148) mengatakan, “organization learning the process through which managers instill in all members of an organization a desire to find new ways to improve organizational effectiveness". Pembelajaran organisasi adalah proses melalui manajer untuk menanamkan kepada semua anggota organisasi untuk menemukan cara-cara baru untuk meningkatkan efektivitas organisasi. Hal senada di ungkapkan oleh John R. Schemerhon, JR, Richard N. Osbon, Mary Uhl-bein dan James G. Hunt (2012:401) mengatakan; "organizational learning is the process of acquiring knowledge and using information to adapt successfully to changing circumstances. for organizations to learn, they must engage in knowledge acquisition, information distribution, information interpretation and organizational retention in adapting successfully to changing circumstances". Pembelajaran organisasi adalah proses memperoleh pengetahuan dan menggunakan informasi untuk beradaptasi dengan sukses untuk keadaan yang berubah. untuk organisasi untuk belajar, mereka harus terlibat dalam akuisisi pengetahuan, distribusi informasi, interpretasi informasi dan retensi organisasi dalam beradaptasi dengan sukses untuk mengubah keadaan.

Hasil penelitian ini senada dengan pendapat beberapa ahli di antaranya adalah Jennifer M. George, dan Gareth R. Jones (2012:85) mengatakan, "organization learning the process through which managers instill in all members of an organization a desire to find new ways to improve organizational effectiveness". Pembelajaran organisasi adalah proses ketua yayasan untuk menanamkan kepada semua dosen dan pegawai untuk menemukan cara-cara baru untuk meningkatkan efektivitas organisasi. Dengan proses pembelajaran organisasi yang tepat akan terwujudnya efektivitas organisasi yang di harapkan dan akan berdampak kepada peningkatan komitmen organisasi dosen dan pegawai terhadap kampus selanjutnya John R. Schemerhon, JR, Richard N. Osbon, Mary Uhlbein and James G. Hunt (2012:401) mengatakan; "organizational learning is the process of acquiring knowledge and using information to adapt successfully to changing circumstances. for organizations to learn, they must engage in knowledge acquisition, information distribution, information interpretation and organizational retention in adapting successfully to changing circumstances". Pembelajaran organisasi adalah proses memperoleh pengetahuan dan menggunakan informasi untuk beradaptasi untuk menuju kesuksesan dan keadaan yang lebih baik. Untuk organisasi dalam proses belajar, kampus harus terlibat dalam akuisisi pengetahuan, distribusi informasi, interpretasi informasi dan retensi organisasi dalam beradaptasi dengan membantu menyediakan sarana dan prasarana dan kebijakan-kebijakan yang mendukung. Dengan proses pembelajaran organisasi berjalan sesuai harapan akan lahirlah kesadaran yang muncul dari dalam diri dosen untuk lebih 
bekerja dengan baik dan secara otomatis akan berdampak kepada komitmen organisasi dimana dosen bekerja.

\section{Pengaruh pemberdayaan terhadap pembelajaran organisasi.}

Dari hasil pengujian hipotesis ketiga dapat disimpulkan bahwa terdapat pengaruh langsung positif pemberdayaan terhadap pembelajaran organisasi dengan nilai koefisien korelasi sebesar 0,330 dan nilai koefisien jalur sebesar 0,330. Ini memberikan makna pemberdayaan berpengaruh langsung terhadap pembelajaran organisasi. Edwin P. Hollander dan Lynn R. Offermann, yang di kutip oleh Ricard L. Daft (2010:271) mendefinisikan pemberdayaan sebagai berikut, "empowerment is power sharing, the delegation of power or authority to subordinates in an organization". Pemberdayaan adalah pembagian kekuasaan, pendelegasian kekuasaan atau wewenang kepada bawahan dalam suatu organisasi. Pendapat lain oleh Robert C. Ford dan Myron D. Fottler yang di kutip oleh John W. Neswtrom (2014:195) mendefinisikan pemberdayaan sebagai berikut, "empowerment is any process that provides greater autonomy to employees through the sharing of relevant information and the provision of control over factors affecting job performance". Pemberdayaan adalah proses yang menyediakan otonomi yang lebih besar kepada karyawan melalui berbagi informasi yang relevan dan penyediaan kontrol atas faktor yang mempengaruhi prestasi kerja. Hal senada di ungkapkan oleh Robert Kreitner, dan Angelo Kinicki (2011:442) mendefinisikan pemberdayaan sebagai berikut, "empowerment is recognizing and releasing into the organization of power that people already have their wealth of useful knowledge, experience and internal motivation." Pemberdayaan adalah perilaku dengan sadar dan melepaskan ke dalam kekuasaan organisasi. Dengan kekayaan pengetahuan yang dimiliki dan bermanfaat bagi organisasi, pengalaman dan motivasi internal seseorang.

Hasil penelitian ini senada dengan pendapat beberapa ahli di antaranya adalah John W. Newstrom (2011:181) menjelaskan bahwa dengan memaksimalkan pemberdayaan dalam proses pembelajaran organisasi akan memberikan dampak yang baik untuk anggota dan organisasi, "empowerment is any process that provides greater autonomy to employess throght the sharing of relevanst imformation and the provision of control over factors affecting job performance. Five broad approaches to empowerment have been suggested. (1) Helping employess achieve job mastery (giving prover training,coaching, and guided experience that will resultin initial success. (2) Allowing more control (giving them discretion over job performance and then holding them accountable for out comes), (3) Providing successful role models (allowing them to observe peers who already perform successfully on the job), (4) Using social reeimforcement and persuasion(giving praise, encouragement, and verbal feedback designed to raise self confidence), (5) Giving emotional support providing reduction of stress and anxiety through better role definition, task assistance caring".

Kutipan di atas menjelaskan bahwa pemberdayaan adalah setiap proses yang memberikan kekuasaan yang lebih besar kepada dosen melalui berbagai informasi yang relevan dan penyediaan akses atas faktor yang mempengaruhi kinerja. Adapun beberapa pendekatan untuk pemberdayaan antara lain: membantu dosen mencapai penguasaan pekerjaan (memberikan pelatihan yang tepat, pembinaan, dan pengalaman yang akan menghasilkan kesuksesan), memungkinkan keleluasaan yang lebih besar (memberi keleluasaan dosen dalam bekerja, kemudian memberikan tanggung jawab 
atas hasil pekerjaan yang telah dikerjakan), memberikan teladan yang sukses (memungkinkan dosen untuk melihat rekan-rekan dosen yang sudah sukses bersikap terhadap pada pekerjaannya), menggunakan penguatan sosial dan kepercayaan (memberikan pujian, dorongan, dan umpan balik verbal yang dirancang untuk meningkatkan kepercayaan diri dosen), dan memberikan dukungan emosional (memberikan pengurangan terhadap stres dan kecemasan terhadap pemberian peran yang lebih baik, bantun tugas jujur).

Pendapat senada di ungkapkan oleh Jay A.Conger and Rabindra N.Kanungo, yang di kutip oleh Ricard L. Daft (2011:181) yang mendefinisikan pemberdayaan sebagai berikut, "increasing employee power heightens motivation for task accomplishment because people improve their own effectiveness, choosing how to do a task and using their creativity". ${ }^{2}$ Meningkatkan kekuatan dosen mempertinggi motivasi untuk penyelesaian tugas karena orang meningkatkan efektivitas dosen sendiri, memilih bagaimana melakukan tugas dan menggunakan kreativitas dalam bekerja. Jones R. Gareth (2010:363) mendefinisikan, "organizational learning is the process throught which managers seek to improve organization members desire and ability to understand and manage the organization and its environment so they make decisions that continuously raise organizational effectivess." Pembelajaran organisasi adalah proses di mana ketua yayasan berusaha untuk meningkatkan keinginan dosen dan kemampuan untuk memahami dan mengelola kampus serta lingkungannya sehingga dosen dapat membuat keputusan yang terus menerus meningkatkan organisasi secara efektif.

\section{PENUTUP}

Kesimpulan: 1)Pemberdayaan berpengaruh langsung positif terhadap komitmen organisasi. Artinya ketepatan dalam proses pemberdayaan yang dirasakan guru mengakibatkan peningkatan komitmen organisasi dosen STIT Al-Amin. 2) Pembelajaran organisasi berpengaruh langsung positif terhadap komitmen organisasi. Artinya pembelajaran organisasi yang tepat mengakibatkan peningkatan komitmen organisasi dosen STIT Al-Amin. 3) Pemberdayaan berpengaruh langsung positif terhadap pembelajaran organisasi. Artinya ketepatan dalam proses pemberdayaan yang dirasakan dosen akan mengakibatkan peningkatan pembelajaran organisasi didiri dosen STIT Al-Amin. Saran: 1) Bagi ketua yayasan STIT Al-Amin, untuk membantu menyediakan sarana prasarana pendukung penunjang proses pembelajaran bagi para dosen, memberikan bantuan baik secara materi ataupun dukungan emosional kepada dosen yang ingin melanjutkan studi doktoral dan memperhatikan setiap kebutuhan dosen selama di kampus. 2)Bagi peneliti lain, dapat dijadikan bahan rujukan dalam rangka peneliti lebih lanjut terkait dengan pemberdayaan dan pembelajaran organisasi terhadap komitmen organisasi.

\section{DAFTAR PUSTAKA}

\section{Ibid}


Baldwin, Timothy T., William H. Bommer, Robert S. Rubbin, Managing Organizational Behavior what Great Managers Know \& Do Second Edition. New York: Mc Graw Hill, 2013.

Colquitt, Jason A., Jeffry A. LePine, Michael J Wesson, organizational behavior improving performance and commitment in the workplace 4 edition. New York: McGraw-Hill, 2015.

Daft, Richard L. Understanding the theory design of organizations 10 Edition. China: South Western Camgage Learning, 2010.

Gareth, Jones R, Organizational theory, design, and change 5 edition. New Jersey: pearson, 2010.

George, Jennifer M., Gareth R. Jones, Understanding and Managing Oganization Behavior 6 Edition. New Jersey: Pearson Prantice Hall, 2012.

George, Jenniver M, Gareth R Jones, Essentials of Contemporary Management 5 edition. New York: Mc Graw Hill, 2013.

Gibson, James L., John M.Ivancevich, James H. Donnelly Jr, Robert Konopaske, Organizational behavior, structure, process 14 edition. New York: McGrawHill,2012.

Greenberg, Jerald, Behavior in organizations 10 edition. England: Pearson, 2011.

Griffin, Ricky W., Gregory Moorhead, Organizational Behavior: Managing People and Organizations, 11 Edition. USA: South-Western, Cengange Learning, 2014.

King, William R., Knowledge Management and Organizational Learning, 2009

Kreitner, Robert, Angelo Kinicki Organizational Behavior 9 edition. New York:Mc GrawHill,2011.

Mullins, Laurie J., Management and Organizational Behaviour,9 edition. England: FT Prentice Hall, 2010.

Newstom, John W., Organizational Behavior 13 Edition. New York: McGraw Hill Companies Inc, 2011.

Quick, James Campbell, Debra L. Nelson, Principles of organizational behavior realities and challenges 8 edition. USA: South Western Cengange Learning, 2013.

Robbins, Stephen P., Timothy A. Judge, organizational behavior 16 edition. England: Perason, 2015.

Saputra, Uhar, Manajemen Pendidikan Perguruan Tinggi. Bandung: Refika Aditmah, 2015. 
Schemerhorn, John R. JR, Richard N. Osborn, Mary Uhl-Bien, James G. Hunt, Organizational Behavior 12 edition. Asia: Wiley, 2012.

Schermerhorn, John R., Introduction to Management 12 edition. Asia: John Wiley \& Sons Pte Ltd, 2013.

Robbins, Stephen P., Timothy A. Judge, Organizational Behavior 16 edition. New Jersey: Prentice Hall Person, 2015. 